\title{
Perawatan Ulang Saluran Akar Insisivus Lateralis Kiri Maksila dengan Medikamen Kalsium Hidroksida-Chlorhexidine
}

\author{
Ni Gusti Ayu Ariani* dan Wignyo Hadriyanto** \\ *Program Studi Konservasi Gigi,PPDGS Fakultas Kedokteran Gigi Univeristas Gadjah Mada \\ **Bagian Konservasi Gigi Fakultas Kedokteran GigiUniversitas Gadjah Mada Yogyakarta \\ *Jl Denta no 1 Sekip Utara, Yogyakarta, e-mail:iga.ariani@yahoo.com
}

\begin{abstract}
ABSTRAK
Banyak faktor yang menyebabkan kegagalan terapi endodontik antara lain pembersihan dan membentuk saluran akar yang tidak sempurna dan obturasi tidak hermetis sehingga menyebabkan kurangnya kemampuan untuk menghilangkan mikroorganisme yang ada. Saluran akar yang terinfeksi membutuhkan suatu medikamen untuk menunjang keberhasilan dalam perawatan saluran akar.Kalsium hidroksida merupakan salah satu bahan medikamen yang efektif karena memiliki sifat antibakteri dengan spektrum luas, pH tinggi, biokompatibilitas baik, mampu menetralkan endotoksin bakteri, memiliki sifat toksik yang paling rendah, serta menstimulasi pembentukan jaringan keras. Tujuan laporan kasus untuk menunjukan keberhasilan perawatan ulang saluran akar gigi insisivus lateralis kiri maksila dengan lesi periapikal menggunakan medikamen kalsium hidroksidachlorhexidine. Pasien wanita umur 53 tahun, gigi insisivus lateralis kiri maksila dengan lesi periapikal.Radiografi tampak obturasi kurang hermetis dan radiolusen daerah periapikal. Perawatan ulang saluran akar,diikuti pemasangan pasak fiber frefabricated dan restorasi porselin fuse metal.Keseimpulan setelah evaluasi setelah enam bulan pasca perawatan ulang saluran akar, radiografi menunjukan radiolusen mengecil dan gigi dapat berfungsi dengan normal.
\end{abstract}

Maj Ked Gi. Juni 2013; 20(1): 52 - 57.

Kata Kunci: perawatan saluran akar ulang, kalsium hidroksida, chlorhexidine

\begin{abstract}
Re-Treatment of Root Canal of Maxillary Left Lateral Incisor with Calcium Hydroxide-Chlorhexidine Medicament. There are many factors that cause failure of endodontic therapy. For instances, incomplete cleaning and shaping of root canal and inadequate obturation that results in difficulty to remove the microorganisms. Infected root canal requires a medicament for the success of the root canal treatment. Calcium hydroxide is one of the effective ingredients as medicament because it has broad spectrum antibacterial properties, high $\mathrm{pH}$, good biocompatibility, and it is able to neutralize bacterial endotoxins, decrease tissue toxicity, and stimulate the formation of hard tissue. The purpose of this case report is to show the success of root canal treatment of the left maxillary lateral incisor with periapical lesions using calcium hydroxide-chlorhexidine medicaments. The patient was a woman aged 53, complaining about her left maxillary lateral incisor with periapical lesion. Based on the radiographic evaluation, there was less hermetic obturation and a radiolucent in the periapical. Root canal re-treatment was continued with fiber prefabricated post and porcelain fused to metal crown. After six months of evaluation and endodontic retreatment, it is found that there is a decrease of radiolucency periapical lesion, and her teeth are able to function normally.

Maj Ked Gi. Juni 2013; 20(1): 52 - 57.
\end{abstract}

Keywords: root canal retreatment, calcium hydroxide, chlorhexidine

\section{PENDAHULUAN}

Perawatan saluran akar (PSA) meru-pakan salah satu perawatan endodontik yang bertujuan untuk membersihkan jaringan pulpa atau mikroorganisme yang terdapat didalam sistem saluran akar sehingga dapat dilakukan pengisian saluran akar dengan baik dan terjadi perbaikan jaringan periapikal. ${ }^{1}$ PSA dikatakan berhasil bila dalam waktu observasi minimal satu tahun tidak terdapat keluhan dan lesi periapikal yang ada dapat berkurang atau tetap. Penyebab kegagalan PSA sangat banyak antara lain obturasi yang tidak sempurna, perforasi akar, resorpsi akar eksternal, lesi periodontal-periradikuler, overfilling, adanya saluran akar yang tertinggal, kista periapikal, tertinggalnya instrument yang patah dalam saluran akar, perforasi dasar foramen nasalis dan kebocoran koronal. ${ }^{2}$ 
Kegagalan PSA yang menyebabkan adanya lesi periapikal memerlukan perawatan saluran akar ulang dengan tujuan menghilangkan bakteri dan mencegah kontaminasi lebih lanjut dengan obturasi yang hermetis dan penutupan koronal yang baik. ${ }^{3}$ Pemahaman tentang anatomi sistem saluran akar memegang peranan penting dalam keberhasilan dan kegagalan perawatan tersebut. Enterococcus faecalis (E. faecalis) ditemukan sembilan kali lebih banyak pada infeksi pasca PSA dibandingkan pada infeksi primer. Pada beberapa kasus bahkan ditemukan $E$. faecalis sebagai satu-satunya bakteri yang ada pada saluran akar yang sudah dilakukan obturasi dengan lesi periapikal ${ }^{4}$. Kalsium hidroksida / $\mathrm{Ca}(\mathrm{OH})_{2}$ merupakan bahan medikamen saluran akar yang efektif karena memiliki sifat antibakteri dengan spektrum yang luas, bersifat biokompatibel terhadap jaringan, mengurangi peradangan jaringan periapeks, serta dapat menstimulasi pembentukan jaringan keras. $\mathrm{Ca}(\mathrm{OH})_{2}$ mempunyai aksi kerja melalui pelepasan ion $\mathrm{Ca}^{2+}$ yang berperan dalam proses mineralisasi jaringan dan ion $\mathrm{OH}^{-}$yang dapat memberikan efek antimikroba melalui peningkatan $\mathrm{pH}$, sehingga terbentuk lingkungan alkalin yang tidak sesuai untuk perkembangan mikroorganisme. ${ }^{5}$

Gigi yang telah dilakukan PSA akan mengalami perubahan karakteristik fisik dan perubahan estetik. Oleh karena itu perlu merencanakan restorasi yang akan digunakan sehingga dapat melindungi sisa jaringan gigi terhadap fraktur. ${ }^{6}$ Gigi yang telah dilakukan PSA memerlukan retensi berupa pasak untuk menyatukan dengan inti, sebagai dukungan restorasiakhir. ${ }^{7}$ Pasak fiber mempunyai beberapa kelebihan, salah satunya modulus elastisitasnya menyerupai dentin sehingga menurunkan resiko fraktur ${ }^{1}$.

Tujuan dari artikel ini untuk menunjukan keberhasilan dari perawatan saluran akar ulang gigi insisivus lateralis kiri maksila dengan lesi periapikal menggunakan medikamen kalsium hidroksida $\left(\mathrm{Ca}(\mathrm{OH})_{2}\right)$ dengan khlorhexidine $(\mathrm{CHx})$.

\section{STUDI KASUS}

Pasien wanita berusia 53 tahun datang ke klinik Spesialis Konservasi Gigi RSCM Prof Soedomo FKGUGM dengan keluhan gigi depan kiri atas kadangkadang sakit jika digunakan untuk menggigit sejak 2 bulan yang lalu. Gigi tersebut sudah pernah dilakukan PSA dilanjutkan dengan restorasi komposit oleh dokter gigi umum kurang lebih satu tahun yang lalu. Pada saat dilakukan pemeriksaan, gigi tersebut tidak sakit.

Pada pemeriksaan obyektif gigi 22 (Gambar 1) tampak restorasi sewarna dengan gigi dalam keadaan masih baik. Peka terhadap tes perkusi, tetapi tidak peka terhadap palpasi, mobilitas normal. Jaringan pendukung gigi dan kebersihan mulut penderita
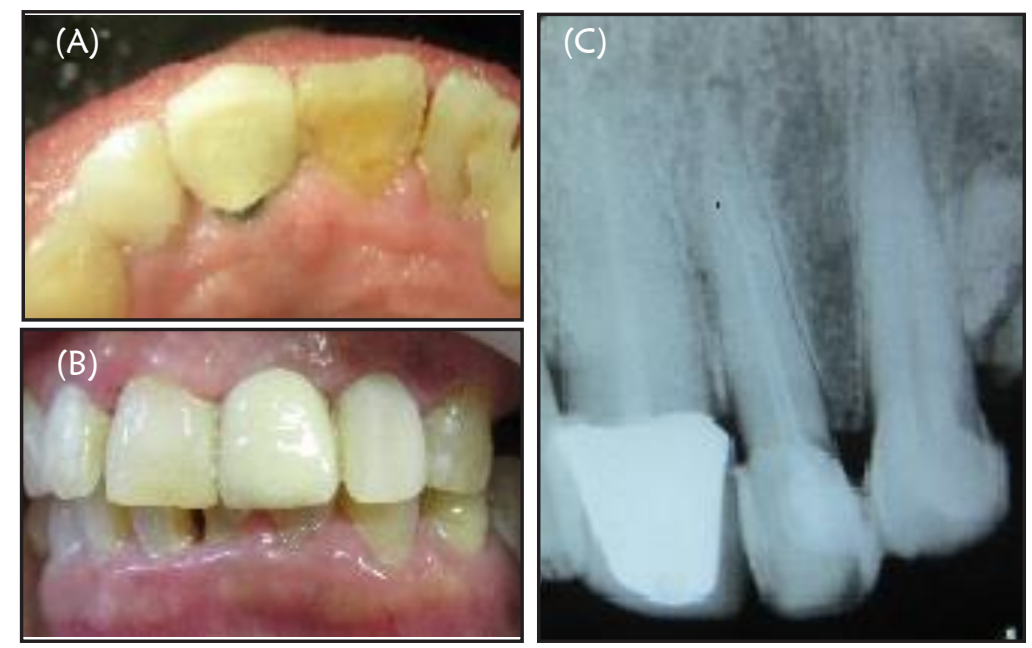

Gambar 1. (A) Gigi 22 pre operatif diliat dari labial; (B) diliat dari palatal; (C) hasil radiograf gigi 22 pre operatif tampak daerah radiolusen pada apikal, pengisian under filling dan tidak hermetic 
sedang. Pada pemeriksaan radiograf gigi 22, tampak gambaran radiopak sepanjang saluran akar (gutta perca), tetapi terlihat tidak hermetis dan tidak mencapai apikal (kurang $5 \mathrm{~mm}$ dari apeks). Bentuk anatomis akar lurus. Pada daerah periapikal terlihat gambaran radiolusen bulat dengan diameter kurang lebih $5 \mathrm{~mm}$.

Diagnosis yang ditegakkan adalah 22 non vital pasca PSA disertai lesi periapikal dengan obturasi underfilling dan tidak hermetis. Rencana perawatan PSA ulang multikunjungan dengan restorasi mahkota jaket porselin fusi metal (PFM) dengan pemasangan pasak fiber prefabricated. Prognosis baik, karena saluran akar lurus dan tidak ada penyempitan saluran akar, iritasi ke daerah periapeks masih sangat minimal, sisa jaringan gigi masih cukup untuk dilakukan restorasi mahkota jaket dan pasien kooperatif.

Pada kunjungan I (2 oktober 2012) dilakukan pemeriksaan subyektif, obyektif, foto intra oral dan radiograf (gambar 1), diagnosis, penentuan rencana perawatan gigi 22 dan dilanjutkan dengan penandatanganan informed consent

Gigi 22 diisolasi dengan rubber dam. Pengambilan gutta perca dilakukan dengan fileheadstroem yang dibantu dengan cairan chloroform serta dilakukan irigasi dengan $\mathrm{NaOCl}$ $2,5 \%$. Pengukuran panjang kerja (PK) dengan cara PK estimasi dari foto radiograf pre operatif yang akan dikonfirmasi dengan apex locatordan didapat PK 22

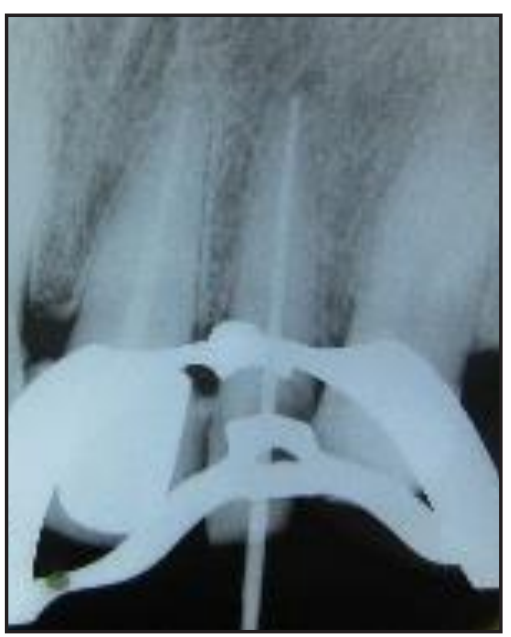

(A) $\mathrm{mm}$. K-File terbesar yang dapat masuk sepanjang PK adalah K-File \#40, dimasukkan ke dalam saluran akar dengan PK 22mm, dikonfirmasikan dengan radiograf (Gambar 2).

Kemudian dilanjutkan dengan preparasi saluran akar tehnik konvensional dengan PK $22 \mathrm{~mm}$. Setiap pergantian file pada preparasi saluran akar, dilakukan irigasi dengan $\mathrm{NaOCL} 2,5 \%$ dan file dilumasi dengan EDTA. Bahan irigasi yang digunakan yaitu $\mathrm{NaOCl} 2,5 \%$, EDTA dan $\mathrm{CH} \times 2 \%$. Dilanjutkan dengan pemberian intra canal medikamen $\mathrm{Ca}(\mathrm{OH})_{2}$ yang dicampur dengan $\mathrm{CHx} 2 \%$ dimasukan ke dalam saluran akar, kemudian ditumpat sementara.

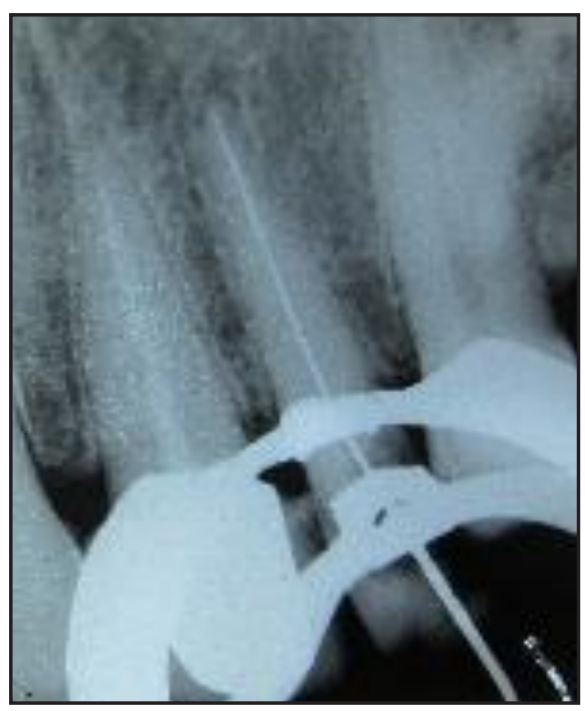

Gambar 2. Radiograf pengukuran PK estimasi K-file \#40

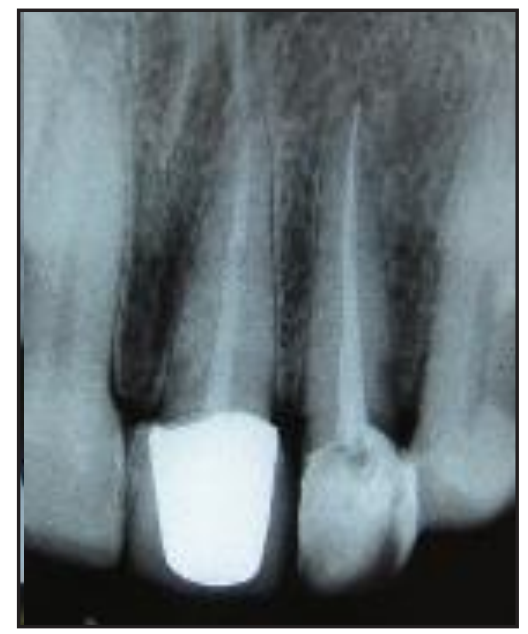

(B)

Gambar 3. Radiograf Master Cone gutta perca (A); hasil obturasi (B) 
Kunjungan II (9 Oktober 2012) Pemeri-ksaan subyektif tidak ada keluhan, tumpatan sementara dibuka, saluran akar diirigasi dengan $\mathrm{NaOCL} 2,5 \%$ dan dilakukan pengepasan guta perca dengan \#40 kemudian dikonfirmasi dengan radiograf (Gambar $3 \mathrm{~A})$. Gutta perca disterilkan dalam larutan $\mathrm{NaOCL}$ $2,5 \%$, dibilas alkohol $70 \%$ dan dikeringkan.Sebelum dilakukan pengisian, saluran aka $r$ diirigasi dengan $\mathrm{NaOCL} 2,5 \%$, EDTA cair 1 menit, dan $\mathrm{CH} \times 30$ detik, dikeringkan dengan paper point. Pengisian saluran akar dengan tehnik kondensasi lateral dengan sealer berbahan epoxy-resin (Topseal, Densply). Setelah saluran akar penuh, gutta perca dipotong sebatas orifis, diberi basis semen seng fosfat dan tumpatan sementara. Foto rongent (gambar 3B)

Pada kunjungan III (16 Oktober). Kontrol PSA. Pasien tidak memiliki keluhan, perkusi dan palpasi negatif, dilanjutkan dengan preparasi pasak dan mahkota jaket porselin fusi metal (PFM). Pasak yang digunakan yaitu pasak fiber prefabricated (Fiberpost,Denstply). Gutta perca dibuang menggunakan Gates glidden drill (2/3 dari panjang gigi didapat $16 \mathrm{~mm}$ dan menyisakan gutta perca $6 \mathrm{~mm}$ ) kemudian menggunakan Peeso reamer dan precission drill. Pengepasan dan dikonfirmasi dengan foto radiografis. Penyemenan dengan semen resin dan dilanjutkan pembuatan inti resin. Cetak menggunakan rubber base, untuk gigi antagonis dilakukan pencetakan dengan alginat. Model dikirimkan ke dental lab.

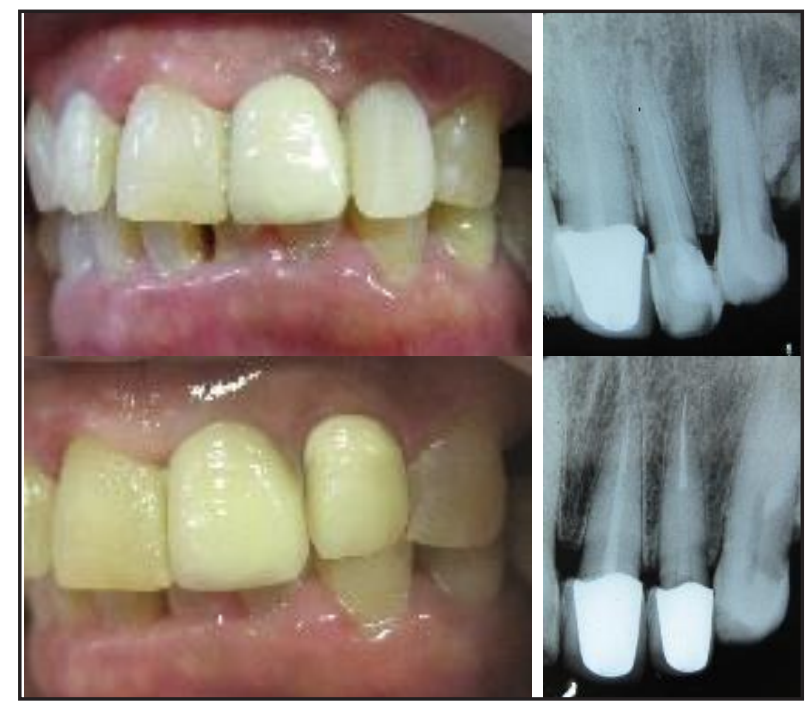

Gambar 4. Foto sebelum dan sesudah perawatan
Kunjungan IV (25 Oktober 2012) dilakukan pemasangan mahkota jaket PFM. Cek warna, kontur, embrasur, kerapatan tepi, oklusi, kontak proksimal, ketahanan, dan hubungan dengan gigi antagonis, penyemanan dengan semen resin (Gambar 4).

Kunjungan V. dilakukan kontrol 6 bulan setelah PSA (Gambar 5), pada pemeriksaan subyektif tidak ada keluhan dan pemeriksaan obyektif perkusi dan palpasi negatif, oklusi tidak ada traumatik, mahkota PFM masih terpasang dengan baik dan pasien merasa nyaman

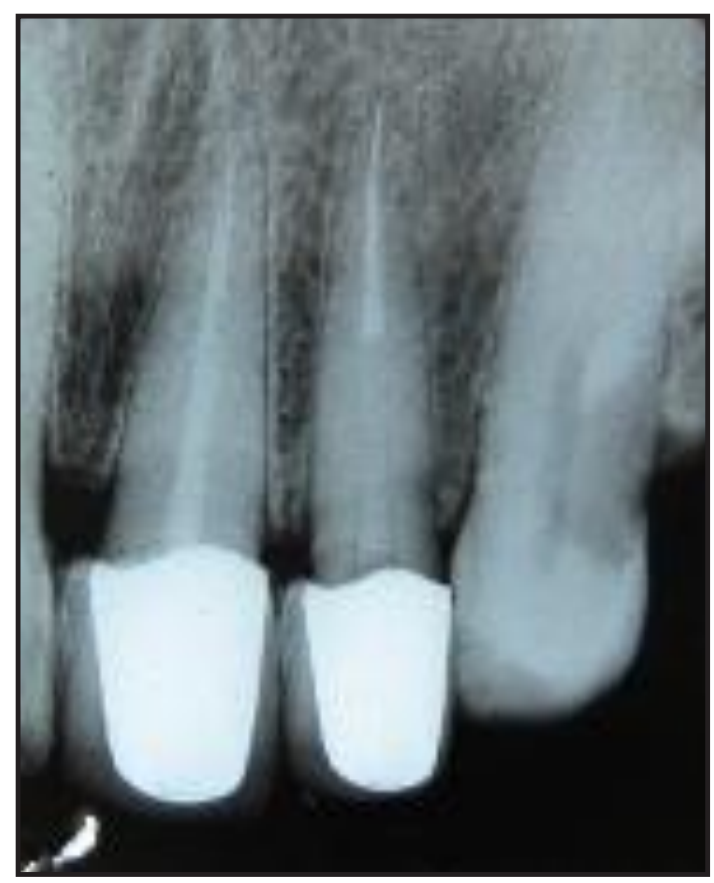

Gambar 5. Foto Radiograf setelah pera-watan 6 bulan

\section{PEMBAHASAN}

Penyebab kegagalan PSA pada kasus ini terlihat bahwa obturasi tidak mencapai apeks (kurang $5 \mathrm{~mm}$ dari apeks), kemungkinan karena instrumentasi yang tidak mencapai PK. Salah satu tujuan PSA adalah preparasi dan pengisian saluran akar secara hermetis, oleh sebab itu ketepatan pengukuran panjang saluran akar hingga pada batas dentin-semen merupakan tahap awal yang penting. ${ }^{8}$ Obturasi memegang peranan penting dalam keberhasilan PSA. Hampir $60 \%$ dari kegagalan perawatan endodontik disebabkan karena obturasi yang tidak sempurna. ${ }^{2}$ 
Infeksi sekunder pada perawatan saluran akar menjadi penyebab utama kegagalan PSA. Bakteri utama penyebab infeksi sekunder pada kegagalan PSA adalah E. faecalis. E. faecalis mempunyai kemampuan penetrasi ke dalam tubuli dentin sehingga memungkinkan bakteri tersebut terhindar dari instrumentasi alat-alat preparasi dan bahan irigasi yang digunakan selama preparasi biomekanikal. Selain itu, bakteri ini mampu mengkatabolisme berbagai sumber energi dan dapat bertahan hidup dalam berbagai lingkungan termasuk $\mathrm{pH}$ alkali dan suhu yang ekstrim. ${ }^{1}$

$\mathrm{Ca}(\mathrm{OH})_{2}$ merupakan bahan medikamen saluran akar yang efektif karena memiliki sifat antibakteri dengan spektrum yang luas, bersifat biokompatibel terhadap jaringan, mengurangi peradangan jaringan periapeks, serta dapat menstimulasi pembentukan jaringan keras. $\mathrm{Ca}(\mathrm{OH})_{2}$ mempunyai aksi kerja melalui pelepasan ion $\mathrm{Ca}^{2+}$ yang berperan dalam proses mineralisasi jaringan dan ion $\mathrm{OH}^{-}$yang dapat memberikan efek antimikroba melalui peningkatan $\mathrm{pH}$, sehingga terbentuk lingkungan alkalin yang tidak sesuai untuk perkembangan mikroorganisme. ${ }^{8}$ Ketika diaplikasikan dalam saluran akar, $\mathrm{Ca}(\mathrm{OH})_{2}$ terurai menjadi ion $\mathrm{Ca}^{2+}$ dan ion $\mathrm{OH}^{-}$yang selanjutnya akan berdifusi melalui tubulus dentinalis. ${ }^{9}$ Dengan sifat basanya menyebabkan sebagian besar mikroorganisme yang ada dalam saluran akar yang terinfeksi tidak mampu bertahan hidup. ${ }^{10}$ Penambahan berbagai substansi dalam bubuk $\mathrm{Ca}(\mathrm{OH})_{2}$ juga dapat meningkatkan sifat antibakteri, radiopasitas, daya alir dan konsistensi dari $\mathrm{Ca}(\mathrm{OH})_{2}$ tersebut. ${ }^{11}$ Bahan pencampur yang ideal mampu membuat pelepasan ion $\mathrm{Ca}^{2+}$ dan $\mathrm{OH}^{-}$ berjalan secara lambat dan bertahap, difusi ke dalam jaringan berjalan lambat dengan kelarutan yang rendah dalam cairan jaringan serta tidak memiliki efek negatif terhadap induksi deposisi jaringan keras. $^{12}$

Chlorhexidine (CHX) telah digunakan sebagai salah satu bahan pencampur medikamen saluran akar karena memiliki sifat antimikroba spektrum luas, mampu menjaga sifat antimikrobanya untuk jangka waktu lama serta pelepasanya lambat sejalan dengan penurunan konsentrasinya. ${ }^{13}$ Kombinasi $\mathrm{Ca}(\mathrm{OH})_{2}$ dan $\mathrm{CH}$ 2\% memiliki sifat antibakteri yang baik, karena pasta kombinasi tersebut mampu berfungsi sebagai barier dalam sistem saluran akar untuk jangka waktu yang lebih lama sehingga dapat menghilangkan lebih banyak mikroorganisme yang bersifat persisten. Kombinasi tersebut juga bersifat biokompatibel tanpa mempengaruhi kemampuan perlekatan bahan pada saat obturasi saluran akar. ${ }^{14}$ Sifat antimikroba $\mathrm{CHx}$ berdasarkan pada interaksi antara molekul bermuatan positif yang ada pada substansi tersebut dengan gugus fosfat bermuatan negatif yang ada pada dinding sel bakteri. Molekul bermuatan positif dari $\mathrm{CHx}$ juga dapat terserap ke dalam dentin untuk mencegah kolonisasi bakteri pada permukaan dentin sehingga dapat menghambat infeksi ulang saluran akar selama periode perawatan. ${ }^{15}$ Penambahan $\mathrm{CHx}$ pada $\mathrm{Ca}(\mathrm{OH})_{2}$ dapat meningkatkan efektifitas medikamen terhadap Enterococcus faecalis. Kombinasi $\mathrm{CH} \times 2 \%$ dengan $\mathrm{Ca}(\mathrm{OH})_{2}$ lebih efektif dibandingkan $\mathrm{Ca}(\mathrm{OH})_{2}$ dengan air. Konsentrasi $\mathrm{CHx}$ yang sering digunakan di bidang endodontik yaitu antara $0.1 \%$ hingga $2 \%$. $\mathrm{CHx}$ memiliki toksisitas yang sangat rendah pada konsentrasi yang lebih tinggi namun medikasi saluran akar dengan konsentrasi $\mathrm{CHx}$ yang lebih tinggi akan meningkatkan resistensi kolonisasi mikroba. ${ }^{15}$

Hilangnya struktur jaringan gigi pasca PSA sangat bervariasi, Pemilihan bahan dan teknik restorasi yang sesuai ditentukan oleh jumlah dan struktur gigi yang tersisa. ${ }^{12}$ Pasak fiber prefabricated menjadi pilihan pada kasus ini karena, pasak fiber memiliki sifat modulus elastisitasnya menyerupai dentin, adaptasi yang baik, bersifat tidak korosif, serta dapat menyebarkan tekanan secara menyeluruh sehingga mencegah terjadinya fraktur akar. Retensi pasak dipengaruhi oleh preparasi, panjang pasak, diameter pasak, tekstur permukaan pasak, dan penggunaan bahan luting. Syarat panjang pasak adalah sama dengan panjang mahkota klinis atau panjang mahkota anatomis, atau setidaknya $2 / 3$ panjang akar. ${ }^{8}$ Panjang saluran pasak pada kasus ini $16 \mathrm{~mm}$ dan menyisakan gutta perca di daerah apikal $6 \mathrm{~mm}$. Sementasi pasak menggunakan semen resin karena telah terbukti keberhasilan sebagai bahan luting pasak fiber. ${ }^{1}$ Pemilihan mahkota jaket PFM sebagai restorasi akhir pada kasus ini karena 
banyak kehilangan jaringan keras gigi dan untuk memperbaiki estetik. Evaluasi menunjukkan keadaan gigi 22 setelah PSA ulang dalam keadaan baik, lesi periapikal mengecil, secara klinis gigi tersebut dapat digunakan dengan baik. Pasien merasa puas.

\section{KESIMPULAN}

Dapat disimpulkan bahwa dalam melakukan PSA ulang diperlukan recleaning dan reshaping secara maksimal. Fiber prefabricated sebagai retensi intra kanal dilanjutkan dengan restorasi mahkota PFM dapat menjadi pilihan restorasi pasca PSA ulang dan adanya pengecilan lesi periapikal menunjukan adanya tanda penyembuhan sehingga gigi dapat bertahan selama mungkin didalam mulut.

\section{DAFTAR PUSTAKA}

1. Anna M, Johanna T. Bonding of composite resin luting cement to fiber reinforced composite root canal posts. J Adhes Dent. 2004; 6: 319-25.

2. Hoen MM, Frank E. Contemporary endodontic retreatments: An analysis based on clinical treatment findings. Journal Endod. 2002; 28: 834-7.

3. Simon S, et all. Apical limit and working length in endodontics. Dent Update. 2009 Apr; 36(3): 14650,153 .

4. Mulyawati E. Peran bahan disinfeksi pada perawatan saluran akar. Majalah Kedokteran Gigi. 2011;1 8(2): 205-9.

5. Hasheminia $S$, et all. The effect of three different calcium hydroxide combinations on root dentine microhardness, Research Journal of Biological Sciences. 2009; 4(1): 121-5.
6. Wagnild G, Mueller K. Restoration of endodontically treated teeth in Cohen S. Hargreaves KM (Editor). Pathways of the pulp. Ed 9. Missouri: Mosby inc; 2006. H. 787-821.

7. Zehnder M. Root canal irrigants. J Endod. 2006; 32: 389-398.

8. Ingle, Bakland. Endodontics. Ed 5. London: Decker; 2002. H. 913-50.

9. George J, Lakshminarayanan L. Anti-microbial effect of various calcium hydroxide preparation- an invitro study, Endodontology. 2001; 13: 2-7.

10. Freire LG, et all. Influence of dentine on $\mathrm{pH} 2 \%$ chlorhexidine gel and calsium hydroxide alone or in combination. Dental Traumatology. 2010; 26: 276-80.

11 Walton R, Torabinejad M. Principles and practice of endodontics. Ed 2. Philadelphia : W.B. Saunders Co; 1996.

12. Fava L, Saunders W. Calcium hydroxide pastes: classification and clinical indications, International Endodontic Journal.1999; 32: 257-82.

13. Poorni $S$, et all. Comparative evaluation of the surface tension and the ph of calcium hydroxyde mixed with five different vehicles. Indian J Dent Res. 2009; 17-20.

14. Delgado R, et all. Antimicrobial effect of calcium hydroxide and chlorhexidine on enterococcus faecalis, J.Endod. 2010; 36:1389-92.

15. Athanassiadis et all. The Use of Calcium Hydroxide, Antibiotics, and Biocides as Antimicrobial Medicaments in Endodontics, J Endod. 2007; 52: S64-82. 